\title{
Phytomass addition and liming in the dynamics of soil chemical and physical attributes
}

\author{
Adição de fitomassa e calagem na dinâmica dos atributos químicos e \\ físicos do solo
}

\author{
Pedro Marques da SILVEIRA ${ }^{1}$; Adriano Stephan NASCENTE²; Maria da Conceição Santana CARVALHO ${ }^{3}$ \\ ${ }^{1}$ Autor para correspondência, Engenheiro Agrônomo, Doutor, Embrapa Arroz e Feijão, Rodovia GO 462, km 12 Santo \\ Antônio de Goiás/GO - CEP 75 375-000, pedro. silveira@embrapa.br \\ ${ }^{2}$ Engenheiro Agrônomo, Doutor, Embrapa Arroz e Feijão, adriano.nascente@embrapa.br \\ ${ }^{3}$ Engenheira Agrônoma, Doutora, Embrapa Arroz e Feijão, maria.carvalho@embrapa.br
}

Recebido em: 12-07-2018; Aceito em: 05-02-2019

\begin{abstract}
In tropical regions, a greater phytomass addition to the soil can help to improve soil quality. Additionally, the use of limestone is a fundamental practice in weathered soils of these regions. The objective of this is study was to quantify the effect of phytomass additions in terms of agricultural systems, limestone rates and application on the dynamics of soil chemical and physical attributes. The experimental design was a randomized complete block in split-plot scheme, with four replicates. The plots consisted of two treatments: agricultural system with raining season and off-season cultivation and agricultural system only with raining season cultivation. Subplots were composed of five limestone rates: $0,1,2,3$, and $4 \mathrm{t} \mathrm{ha}^{-1}$. Subsubplots were two limestone management treatments: with and without incorporation. The experiment was conducted during four agricultural seasons, determining initial and final soil physical and chemical attributes, biomass production, and accumulated grain yield. The agricultural system with off-season cultivation increased the organic matter and calcium and magnesium contents in the topsoil. There was no effect of liming with up to $4 \mathrm{t} \mathrm{ha}^{-1}$ on soil chemical attributes. At the end of four years, soil density was lower and macroporosity was higher in the topsoil. In the four-year period, agricultural systems with off-season cultivation (millet and maize/brachiaria intercropping) provided greater grain and straw yields than agricultural systems without off-season cultivation.
\end{abstract}

Additional keywords: agricultural system; cerrado; limestone; no-tillage system; soil correction.

\section{Resumo}

Em regiões tropicais, o maior aporte de fitomassa ao solo pode auxiliar na melhoria da qualidade do solo. Adicionalmente, o uso de calcário é prática fundamental em solos intemperizados dessas regiões. O objetivo do trabalho foi quantificar o efeito de aportes de fitomassa em termos de sistemas agrícolas, doses e formas de aplicação de calcário sobre a dinâmica dos atributos químicos e físicos do solo. O delineamento utilizado foi em blocos ao acaso, no esquema de parcelas subsubdivididas, com quatro repetições. As parcelas foram constituídas por dois tratamentos: sistema agrícola com safra e safrinha, e sistema agrícola somente com safra. As subparcelas foram compostas por cinco doses de calcário: $0 ; 1 ; 2 ; 3$ e $4 \mathrm{t} \mathrm{ha}^{-1}$. As subsubparcelas foram dois tratamentos de manejo do calcário: com e sem incorporação. $O$ experimento foi conduzido por quatro safras agrícolas, em que se determinaram os atributos químicos e físicos iniciais e finais do solo, a produção de biomassa e a produtividade acumulada de grãos. O sistema agrícola com safrinha aumentou os teores de matéria orgânica e de cálcio e magnésio na camada superficial do solo. Não houve efeito da calagem com até $4 \mathrm{t} \mathrm{ha}^{-1}$ sobre os atributos químicos do solo. No final de quatro anos, a densidade do solo foi menor, e a macroporosidade foi maior na camada superficial do solo. No período de quatro anos, os sistemas agrícolas com safrinha contendo milho e braquiária e milheto proporcionaram maiores produtividades de grãos e palha que os sistemas agrícolas sem safrinha.

Palavras-chave adicionais: calcário; cerrado; correção do solo; sistema agrícola; sistema plantio direto.

\section{Introduction}

Tropical soils such as those of the Brazilian Cerrado are naturally acidic due to high rainfall, which causes leaching of soil bases, reduced soil fertility, and increased acidity (Caires et al., 2006). It then becomes necessary to correct soil acidity and fertility so that there is no reduction in plant development (Fageria \& Nascente, 2014). Thus, an adequate and balanced nutrient supply provides better crop development, with a positive impact on grain yield (Pagani \& Mallarino, 2012). 
The adoption of the no-tillage system (NTS) in Brazil occurred assuming that the suppression of soil tillage and the maintenance of crop straws on the soil surface would constitute sufficient processes to minimize erosion and to remedy soil degradation (Denardin \& Kochhann, 1993). However, the use of NTS without its main precepts - initial chemical and physical correction of the soil profile, crop rotation, and phytomass maintenance at the soil surface - has resulted in degradation of soil attributes, as evidenced by the strong chemical and physical stratification of the 0-20 cm depth layer (Nascente et al., 2014).

In most grain producing areas using NTS, soil acidity correction has been performed by limestone application to the surface, without incorporation (Soratto \& Crusciol, 2008). Notwithstanding, limestone reaction is usually limited to the site of its application/incorporation because it presents low mobility in the soil, which causes a greater delay in the corrective reaction in the soil, mainly in the period close to its application (Caires et al., 2006; Soratto \& Crusciol, 2008). According to Caires et al. (2006), results in field conditions show that limestone movement in depth varies according to time and amount applied, soil class, climatic conditions, use of acid fertilizers, and cultivation system. The authors add that the limestone effect, when not incorporated, may take more than two years to reach the soil layer of $10-20 \mathrm{~cm}$. Thus, this delay in limestone reactions to the soil can hinder the development of agricultural crops.

The study of technologies that improve the environment for faster crop development may complement broadcast limestone application without incorporation. In this sense, diversifying production systems by increasing the number of havests per agricultural year and the phytomass addition (especially of roots) to the soil has become a technique of significant relevance to remedy the soil structure (Ceccon, 2007). Pacheco et al. (2011) reported that the use of cover crops in agricultural systems contributes to a greater cycling of nutrients, thus increasing soil nutrient contents. Additionally, in the notillage system, soil movement is restricted to the sowing row, but the systematic occurrence of machinery traffic causes compaction at the soil surface (Tormena et al., 1998). This highlights the importance of using cover plants with a vigorous root system to avoid soil compaction.

However, in the tropical region, studies of the use of limestone on the surface, without incorporation, along with greater phytomass contribution to soil physical and chemical attributes, are still scarce (Carmeis Filho et al., 2017). The present study quantifies the effect of different phytomass addition in terms of agricultural systems, limestone rates and application on the dynamics of soil chemical and physical attributes.

\section{Materials and methods}

The experiment was installed in the experimental area of Embrapa Rice and Beans, in Santo Antônio de Goiás city, GO, whose geographical coordinates are: $16^{\circ} 28^{\prime} 00^{\prime \prime} S$ latitude, $49^{\circ} 17^{\prime} 00^{\prime \prime}$ W longitude, and altitude of 823 meters. According to the Köppen classification, the climate of the region is tropical of savanna, type Aw (Alvares et al., 2014). Thus, there are two well defined seasons, normally dry from May to September (autumn/winter), and rainy from October to April (spring/summer); the average rainfall in the period from 1982 to 2017 at the Embrapa Rice and Beans climatological station was $1,484.7 \mathrm{~mm}$. The average annual temperature is $22.7^{\circ} \mathrm{C}$, ranging from $14.2^{\circ} \mathrm{C}$ to $34.8^{\circ} \mathrm{C}$.

The soil is classified as Acric Red Latosol, with clayey texture $\left(554 \mathrm{~g} \mathrm{~kg}^{-1}\right.$ clay, $111 \mathrm{~g} \mathrm{~kg}^{-1}$ silt, and $335 \mathrm{~g} \mathrm{~kg}^{-1}$ sand). Chemical and physical soil analyses in the 0-0.1 $\mathrm{m}$ and 0.1-0.2 $\mathrm{m}$ layers prior to the installation of the experiment, in 2013, are shown in Table 1. The area has been conducted in NTS for five consecutive years, with soybean or maize cultivation in the growing season and common bean cultivation in the winter.

Table 1 - Chemical and physical soil analysis of the experimental area prior to the installation of the experiment.

\begin{tabular}{|c|c|c|c|c|c|c|c|}
\hline $\begin{array}{l}\text { Depth } \\
(\mathrm{m})\end{array}$ & $\begin{array}{c}\mathrm{pH} \\
\text { (water } 1: 2,5 \text { ) }\end{array}$ & $\mathrm{Ca}$ & $\begin{array}{c}\mathrm{Mg} \\
\text { nolc } \mathrm{dr}\end{array}$ & Al & $\begin{array}{c}P \\
-\end{array}$ & K & $\begin{array}{c}\text { SOM } \\
\left(\mathrm{g} \mathrm{kg}^{-1}\right)\end{array}$ \\
\hline $0-0.1$ & 5.7 & 15.1 & 12.0 & 0.5 & 18.7 & 97 & 36.0 \\
\hline $0.1-0.2$ & 5.1 & 7.3 & 4.8 & 1.2 & 10.7 & 89 & 18.2 \\
\hline $\begin{array}{l}\text { Depth } \\
(\mathrm{m})\end{array}$ & $\mathrm{Cu}$ & $\begin{array}{l}\mathrm{Fe} \\
---(n\end{array}$ & Mn & $\mathrm{Zn}$ & $\begin{array}{c}\mathrm{SD} \\
\left(\mathrm{g} \mathrm{cm}^{-3}\right.\end{array}$ & \multicolumn{2}{|c|}{----- (\%) ----- } \\
\hline $0-0.1$ & 1.50 & 40 & 9.2 & 3.08 & 1.40 & 36.6 & 10.9 \\
\hline $0.1-0.2$ & 1.62 & 31 & 4.9 & 3.34 & 1.41 & 32.0 & 11.8 \\
\hline
\end{tabular}

SOM - soil organic matter, SD - soil density, MIC - microporosity, MAC- macroporosity

The experimental design was a randomized complete block in a split-plot scheme, with four replicates. Plots consisted of two treatments: agricultural system with off-season cultivation and agricultural system without off-season cultivation. Subplots were composed of five limestone rates: 0,1 , 2 , 3 , and $4 \mathrm{th}^{-1}$, respectively, $0 ; 0.5 ; 1 ; 1.5$; and 2 times of liming recommendation for the region (Sousa \& Lobato, 2004). Subsubplots were two limestone management treatments: with and without incorporation. Plots were $12 \mathrm{~m}$ long by $7.2 \mathrm{~m}$ wide. Agricultural systems used and amount of $\mathrm{P}_{2} \mathrm{O}_{5}$ and $\mathrm{K}_{2} \mathrm{O}$ applied in crop fertilization are shown in Table 2. 
Table 2 - Crops implanted in agricultural systems and quantities of $\mathrm{P}_{2} \mathrm{O}_{5}$ and $\mathrm{K}_{2} \mathrm{O}$ applied in crop fertilization during 2013-2017.

\begin{tabular}{|c|c|c|c|c|c|c|c|c|c|}
\hline \multirow{2}{*}{$\begin{array}{l}{ }^{1} \text { Agricultural } \\
\text { systems }\end{array}$} & \multicolumn{8}{|c|}{ Harvest crop $\left(\mathrm{kg} \mathrm{ha}^{-1}\right)$} & \multirow{3}{*}{$\begin{array}{c}\text { Total } \\
\left(\mathrm{kg} \mathrm{ha}^{-1}\right)\end{array}$} \\
\hline & $2013 / 14$ & 2014 & $2014 / 15$ & 2015 & $2015 / 16$ & 2016 & $2016 / 17$ & 2017 & \\
\hline $\begin{array}{l}\text { With off- } \\
\text { season crop }\end{array}$ & $\begin{array}{c}\text { Common } \\
\text { bean }\end{array}$ & ${ }^{2} M+B$ & Soybean & Millet & Maize & Millet & Soybean & Millet & \\
\hline $\begin{array}{l}\mathrm{P}_{2} \mathrm{O}_{5} \\
\mathrm{~K}_{2} \mathrm{O}\end{array}$ & $\begin{array}{r}104.0 \\
0.0 \\
\end{array}$ & $\begin{array}{l}90.0 \\
45.0 \\
\end{array}$ & $\begin{array}{r}105.0 \\
52.5 \\
\end{array}$ & $\begin{array}{l}- \\
-\end{array}$ & $\begin{array}{r}120.0 \\
60.0 \\
\end{array}$ & - & $\begin{array}{l}60.0 \\
54.0 \\
\end{array}$ & $\begin{array}{l}- \\
- \\
\end{array}$ & $\begin{array}{l}479.0 \\
211.5 \\
\end{array}$ \\
\hline $\begin{array}{l}\text { Without off- } \\
\text { season crop }\end{array}$ & $\begin{array}{c}\text { Common } \\
\text { bean }\end{array}$ & - & Soybean & - & Maize & - & Soybean & - & \\
\hline $\begin{array}{l}\mathrm{P}_{2} \mathrm{O}_{5} \\
\mathrm{~K}_{2} \mathrm{O}\end{array}$ & $\begin{array}{r}104.0 \\
0.0\end{array}$ & $\begin{array}{l}- \\
-\end{array}$ & $\begin{array}{r}105.0 \\
52.5\end{array}$ & $\begin{array}{l}- \\
-\end{array}$ & $\begin{array}{r}120.0 \\
60.0\end{array}$ & $\begin{array}{l}- \\
-\end{array}$ & $\begin{array}{l}60.0 \\
54.0\end{array}$ & $\begin{array}{l}- \\
-\end{array}$ & $\begin{array}{l}389.0 \\
166.5\end{array}$ \\
\hline
\end{tabular}

${ }^{1}$ Agricultural system with off-season crop and agricultural system without off-season crop; ${ }^{2} \mathrm{M}+\mathrm{B}=$ intercropping of maize and Urochloa brizantha.

Limestone was added and incorporated in the corresponding treatments, with a plowing harrow, at $0.15 \mathrm{~m}$ depth. These procedures were performed after the first soil sampling, carried out in October 2013, for the initial evaluation of soil chemical and physical attributes. These same attributes were evaluated at the end of the study, in October 2017 (four years later), after the last harvest of the agricultural crop.

Soil samples were collected at depths of 0-0.1 $\mathrm{m}$ and 0.1-0.2 m. The following were evaluated for chemical characterization (disturbed samples): $\mathrm{pH}$, $\mathrm{Al}, \mathrm{H}+\mathrm{Al}, \mathrm{Ca}, \mathrm{Mg}, \mathrm{P}, \mathrm{K}, \mathrm{Cu}, \mathrm{Fe}, \mathrm{Zn}, \mathrm{Mn}$, and organic matter, considering ten simple samples to form a composite sample using method proposed by Donagema et al. (2011). The $\mathrm{pH}$ was determined in water (1:2.5); $\mathrm{Ca}$ and $\mathrm{Mg}$ were extracted from the soil in $1 \mathrm{~N} \mathrm{KCl}$, and phosphorus and potassium in Mehlich-1 solution $\left(0.5 \mathrm{~N} \mathrm{HCl}+0.025 \mathrm{~N} \mathrm{H}_{2} \mathrm{SO}_{4}\right)$. Organic matter content was determined by the Walkley-Black method (Walkley \& Black, 1934).

For physical characterization, undisturbed samples were collected at the same depths to determine soil density, microporosity, and macroporosity. Samples were collected only in agricultural systems treated with two tons of limestone with incorporation. This was decided given the difficulty of this sampling to be made in all treatments, and to understanding that among these treatments, limestone rates would have less effect on soil physical attributes. These laboratory analyses were performed according to the methods presented by Donagema et al. (2011).

The experiment started in the 2013-14 summer growing season, with the planting of common bean (Phaseolus vulgaris L.) in November, in all treatments. The cultivar planted was 'Agreste', with a row spacing of $0.45 \mathrm{~m}$ and using 10-12 seeds per meter. Sowing fertilization corresponded to $200 \mathrm{~kg}$ monoammonium phosphate (MAP), which has $12 \% \mathrm{~N}$ and $50 \% \mathrm{P}_{2} \mathrm{O}_{5}$. Because of the high $\mathrm{K}$ level already existing in the soil, this element was not added. A notillage seeder-fertilizer was used.

In March 2014, after common bean harvest, maize was sown intercropped with brachiaria (Urochloa brizantha) in the agricultural system with offseason cultivation. The corn hybrid used was 'BRS 1060', with a row spacing of $0.90 \mathrm{~m}$ and using six seeds per meter. Sowing fertilization consisted of $300 \mathrm{~kg} \mathrm{ha}^{-1}$ of the formula $5-30-15\left(\mathrm{~N}-\mathrm{P}_{2} \mathrm{O}_{5}-\mathrm{K}_{2} \mathrm{O}\right)$; $60 \mathrm{~kg} \mathrm{ha}^{-1}$ nitrogen as urea was used for topdressing.

Soybean cultivar 'BRS 8160RR' was sown on $11 / 2014$, with a row spacing of $0.45 \mathrm{~m}$ and using 15 seeds per meter. Planting fertilization consisted of 350 $\mathrm{kg} \mathrm{ha}^{-1}$ of the formula 5-30-15 $\left(\mathrm{N}-\mathrm{P}_{2} \mathrm{O}_{5}-\mathrm{K}_{2} \mathrm{O}\right)$.

In the 2015-2016 summer growing season, maize hybrid 'BRS 1060' was planted in all treatments, with a row spacing of $0.90 \mathrm{~m}$ and using six seeds per meter. Sowing fertilization consisted of $400 \mathrm{~kg} \mathrm{ha}^{-1}$ of the formula 5-30-15 (N- $\left.\mathrm{P}_{2} \mathrm{O}_{5}-\mathrm{K}_{2} \mathrm{O}\right) ; 115 \mathrm{~kg} \mathrm{ha}^{-1}$ nitrogen as urea was used for topdressing.

Millet was planted in the off-season of 2015, 2016, and 2017 in the agricultural system with offseason cultivation. Cultivar 'ADR 300' was used, at a row spacing of $0.45 \mathrm{~m}$. There was neither sowing fertilization nor topdressing fertilization. Millet biomass at maturity was cut and left on the soil surface. Subsequently, it was quantified for yield in $\mathrm{kg} \mathrm{ha}^{-1}$ in sampling of $1 \mathrm{~m}^{2}$.

The cultural traits of all crops were used when necessary to keep crops free of weeds, pests, and diseases.

Data on chemical and physical attributes, accumulated straw production (sum of straw production in all harvests), cumulative grain yield (sum of the grain yield of crops in all harvests), and accumulated grain + straw production (sum of straw production and grain production in all harvests) were submitted to analysis of variance. When significant, means were compared by the Tukey test $(p<0.05)$. Regression test was performed for limestone rates. The statistical package SAS (SAS, 1999) was used.

\section{Results and discussion}

The agricultural systems with and without offseason cultivation did not affect soil chemical attributes (Tables 3 and 4). Thus, biomass contribution from more than one annual crop, including millet, was not enough to affect these attributes. It should be noted that during the three growing seasons, millet cultivation did not receive neither sowing fertilization nor 
topdressing fertilization. Sowing fertilizations used, totaling $479 \mathrm{~kg} \mathrm{ha}^{-1}$ and $389 \mathrm{~kg} \mathrm{ha}^{-1} \mathrm{P}_{2} \mathrm{O}_{5}$ and $211.5 \mathrm{~kg} \mathrm{ha}^{-1}$ and $166.5 \mathrm{~kg} \mathrm{ha}^{-1} \mathrm{~K}_{2} \mathrm{O}$ in the four years, respectively, for systems with and without off-season cultivation (Table 2), did not have sufficient magnitude to alter soil chemical attributes. Millet is considered a major nutrient recycler (Altmann, 2001). However, the amount of nutrients recycled will depend both on nutrient content in the leaf limb and on dry matter yield (Braz et al., 2004), which may be affected by residual fertilization of the summer crop (Carvalho \& Nascente, 2014). According to Pacheco et al. (2011), millet production can reach up to 15 tons per hectare of phytomass; notwithstanding, when planted in the offseason, it rarely exceeds 5 tons per hectare. In addition, changes in soil chemical attributes by the effect of phytomass addition require more time than that used in the present study. Nascente et al. (2017), working with cover crops before upland rice cultivation in Mozambique, also did not find significant differences between treatments for soil chemical and physical attributes. The authors attributed the result to the short time of development of cover plants in the area.

Table 3 - pH, calcium (Ca), magnesium (Mg), aluminium (Al), hydrogen + aluminium $(\mathrm{H}+\mathrm{Al})$, phosphorus $(\mathrm{P})$ and potassium $(\mathrm{K})$ in the soil due to the agricultural system, doses and incorporation of limestone, soil depth and year.

\begin{tabular}{|c|c|c|c|c|c|c|c|}
\hline \multirow{2}{*}{ Treatment } & \multirow{2}{*}{$\begin{array}{c}\mathrm{pH} \\
\mathrm{H}_{2} \mathrm{O}\end{array}$} & \multirow{2}{*}{\multicolumn{4}{|c|}{$\begin{array}{llll}\mathrm{Ca} & \mathrm{Mg} & \mathrm{Al} & \mathrm{H}+\mathrm{Al} \\
- & & \end{array}$}} & \multirow{2}{*}{\multicolumn{2}{|c|}{$P \underset{(m g ~ d m}{-3})$}} \\
\hline & & & & & & & \\
\hline With off-season crop & 5.48 & 13.0 & 8.3 & 1.4 & 33.0 & 12.5 & 94 \\
\hline Without off-season crop & 5.43 & 13.2 & 8.0 & 1.5 & 33.4 & 11.6 & 93 \\
\hline $\mathrm{IL}$ & 5.49 & $14.1 \mathrm{a}$ & $8.5 \mathrm{a}$ & 1.4 & 33.2 & 12.3 & $98 \mathrm{a}$ \\
\hline No IL & 5.42 & $12.1 \mathrm{~b}$ & $7.7 \mathrm{~b}$ & 1.5 & 33.2 & 11.8 & $89 \mathrm{~b}$ \\
\hline Limestone $\left(\mathrm{t} \mathrm{ha}^{-1}\right) \quad 0$ & 5.46 & 13.6 & 8.2 & 1.4 & 33.2 & 12.0 & 95 \\
\hline Limestone $\left(\mathrm{t} \mathrm{ha}^{-1}\right) 1$ & 5.46 & 13.4 & 8.0 & 1.4 & 33.0 & 12.6 & 93 \\
\hline Limestone $\left(\mathrm{t} \mathrm{ha}^{-1}\right) 2$ & 5.43 & 12.4 & 7.6 & 1.5 & 33.4 & 11.0 & 93 \\
\hline Limestone $\left(\mathrm{t} \mathrm{ha}^{-1}\right) 3$ & 5.46 & 13.3 & 8.5 & 1.3 & 33.2 & 12.5 & 96 \\
\hline Limestone $\left(\mathrm{t} \mathrm{ha}^{-1}\right) 4$ & 5.47 & 12.8 & 8.2 & 1.4 & 32.8 & 12.2 & 92 \\
\hline SD $(m) 0-0,1$ & 5.42 & 13.0 & 8.0 & $1.5 \mathrm{a}$ & $35.4 \mathrm{a}$ & 12.0 & 92 \\
\hline$S D(m) 0,1-0,2$ & 5.49 & 13.2 & 8.2 & $1.3 b$ & $31.0 \mathrm{~b}$ & 12.1 & 95 \\
\hline Year 2013 & $5.39 \mathrm{~b}$ & $11.2 \mathrm{~b}$ & $8.4 \mathrm{a}$ & $1.7 \mathrm{a}$ & $40.0 \mathrm{a}$ & $14.7 \mathrm{a}$ & $93 \mathrm{a}$ \\
\hline Year 2017 & $5.52 \mathrm{a}$ & $15.0 \mathrm{a}$ & $7.8 \mathrm{a}$ & $1.1 \mathrm{~b}$ & $26.4 \mathrm{~b}$ & $9.4 \mathrm{~b}$ & $95 \mathrm{a}$ \\
\hline Factors & & & & F test & & & \\
\hline $\begin{array}{l}\text { Incorporation or not of } \\
\text { limestone (INC) }\end{array}$ & & $<0.0001$ & 0.003 & & & & 0.0085 \\
\hline SD & & & & 0.0369 & $<0.0001$ & & \\
\hline Year & 0.0045 & $<0.0001$ & & $<0.0001$ & & & \\
\hline INC*SD & & $<0.0001$ & 0.018 & & 0.0085 & & \\
\hline SD*Year & & & & & 0.0007 & & \\
\hline
\end{tabular}

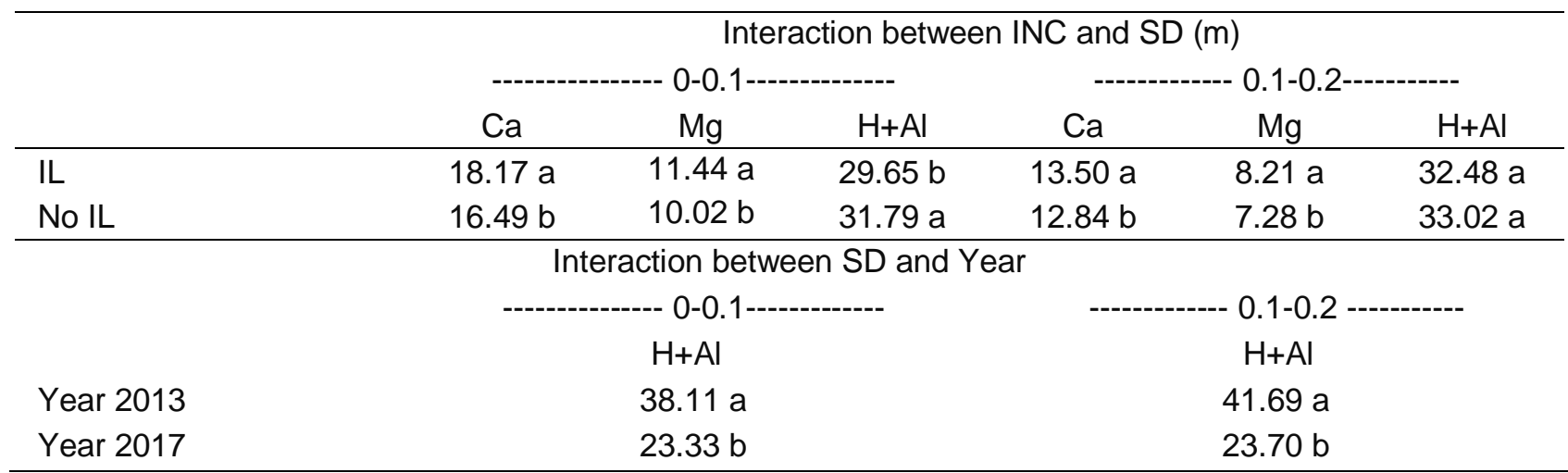

IL - with incorporated limestone, INC - incorporation or not of limestone (a factor), SD - soil depth; Means followed by the same lower-case letter in the column do not differ by $\mathrm{F}$ test $(p>0.05)$

Limestone incorporation did not promote changes neither in $\mathrm{pH}$ nor in the levels of $\mathrm{Al}, \mathrm{H}+\mathrm{Al}$ and $\mathrm{P}$ (Table 3), $\mathrm{Cu}, \mathrm{Mn}, \mathrm{Zn}$, and soil organic matter (Table
4) compared to the treatment without incorporation. On the other hand, it provided higher levels of $\mathrm{Ca}, \mathrm{Mg}, \mathrm{K}$, and $\mathrm{Fe}$ compared the non-incorporation of the 
corrective. This was expected, since dolomitic limestone has calcium and magnesium in its formulation and would increase levels of these nutrients in the soil. Corroborating this information, Gatiboni et al. (2003) observed increased $\mathrm{Ca}$ and $\mathrm{Mg}$ levels in depth by limestone application. However, this non-effect of liming on $\mathrm{pH}$ contradicts results reported by Caires et al. (2006), who observed that liming with or without incorporation provides greater control of soil acidity in the $0-5 \mathrm{~cm}$ layer one year after its application, which can reach $10-20 \mathrm{~cm}$ after two and a half years. Gatiboni et al. (2003) add that these in-depth reactions can occur in up to 58 months. Carmeis Filho et al. (2017) also reported that surface limestone application was efficient to correct $\mathrm{pH}$ and reduce in-depth effects of Al. Additionally, Caires et al. (2006) emphasized that when limestone is incorporated, a larger reaction occurs in the soil layer of 5-10 and $10-20 \mathrm{~cm}$.

Table 4 - Copper $(\mathrm{Cu})$, iron (Fe), manganese (Mn), zinc $(\mathrm{Zn})$ and organic matter in the soil due to the agricultural system, doses and incorporation of limestone, soil depth and year.

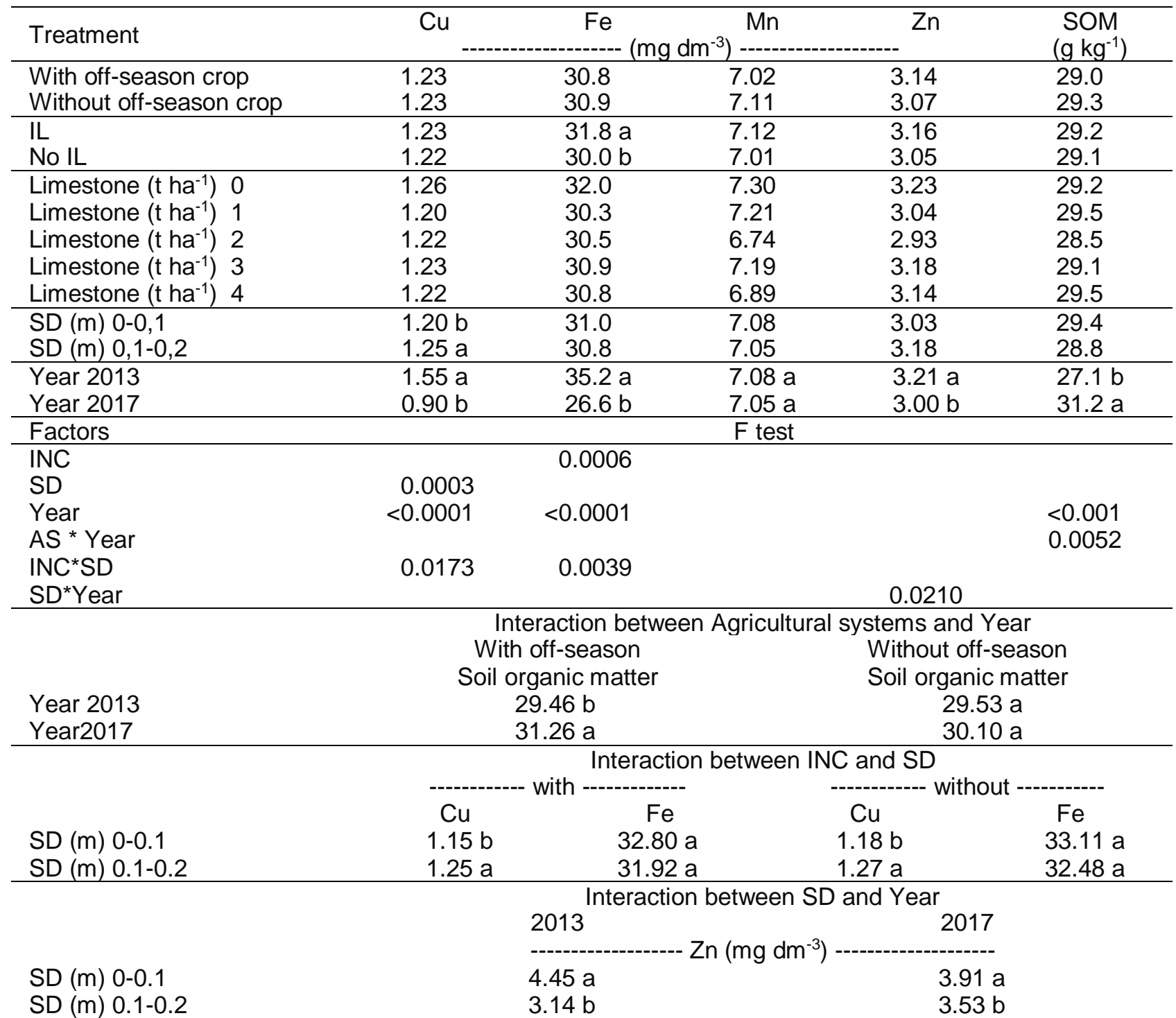

Factors: AS - agricultural systems (With off-season crop and Without off-season crop), INC - incorporation or not of limestone, SD soil depth; Means followed by the same lower-case letter in the column do not differ by $F$ test $(p>0.05)$. SOM - soil organic matter.

The increase of limestone rates (application of up to $4 \mathrm{t} \mathrm{ha}^{-1}$ ) was not efficient to alter soil chemical attributes (Tables 3 and 4) under the conditions of this study. In part, this result can be attributed to the fouryear interval between limestone application and the soil sampling to evaluate chemical changes due to liming. Reacidification may have occurred in this period due to acidifying processes occurring naturally in the soil. This result corroborates the information of Caires et al. (1998), who observed that soils with NTS implanted on a conventional cultivation system did not show important responses to limestone application in the $0-20 \mathrm{~cm}$ layer, even though at $\mathrm{pH} 4.5$ (in $\mathrm{CaCl}_{2}$ ) and with $32 \%$ of base saturation. Also, in the present experiment, soil organic matter contents were high (Sousa \& Lobato, 2004), $36 \mathrm{~g} \mathrm{~kg}^{-1}$, which may have 
contributed to not obtaining differences between results of soil chemical attributes with limestone application. Organic matter acts as a buffer in the soil, aiding the system's resilience (Fageria \& Nascente, 2014).

Comparing the initial (2013) and final (2017) years, $\mathrm{pH}, \mathrm{Ca}$, and soil organic matter were higher in the final year; on the other hand, $\mathrm{Al}, \mathrm{H}+\mathrm{Al}, \mathrm{P}, \mathrm{Cu}, \mathrm{Fe}$, and $\mathrm{Zn}$ showed lower values in the final year (Tables 3 and 4). The reduction of $\mathrm{Al}$ and $\mathrm{H}+\mathrm{Al}$ with limestone application was expected, since the use of limestone is aimed at reducing $\mathrm{H}$ and $\mathrm{Al}$ contents in the soil solution (Fageria \& Nascente, 2014). Moreover, decreased values of $\mathrm{P}, \mathrm{Cu}, \mathrm{Fe}$, and $\mathrm{Zn}$ are probably due to the requirement by the agricultural crops. In the interaction between the use or non-use of off-season cultivation and the initial and final year, off-season cultivation provided significant increases in soil organic matter content, which can be explained by the greater phytomass contribution to the soil. According to
Fageria \& Nascente (2014), the increase of soil organic matter content is directly related to the greater contribution of organic material to this soil. In this way, the different limestone rates and the addition of organic material were not enough to alter soil attributes. On the other hand, the use of no-tillage system for four consecutive harvests provided increases in these attributes, notably in soil organic matter. According to Pacheco et al. (2011), soil organic matter levels tend to increase with increasing periods under no-tillage system.

Regarding soil physical attributes, agricultural systems with and without off-season cultivation did not differ neither in soil density nor in macro- and microporosity (Table 5). The agricultural system with off-season cultivation involved more machinery traffic related to the planting and harvesting of maize and offseason millet, but nevertheless did not alter the values of soil physical attributes.

Table 5 - Density, microporosity and macroporosity of the soil due to the agricultural system, soil depth and year of evaluation.

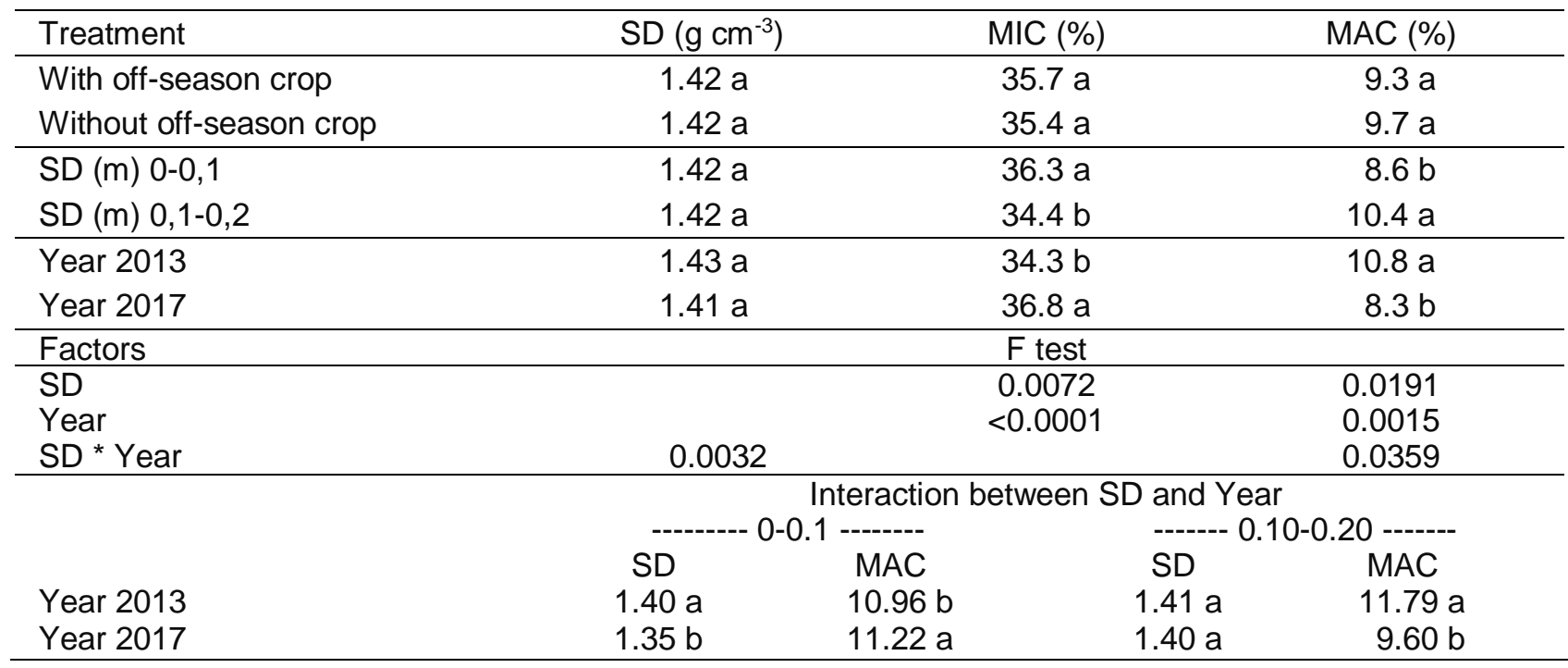

Factors: AS - agricultural systems (With off-season crop and Without off-season crop), SD soil depth; MIC - microporosity, MAC - macroporosity; Means followed by the same lower-case letter in the column do not differ by $F$ test $(p>0.05)$.

Compaction changes soil physical properties, usually increasing density and decreasing total porosity and aeration porosity (Carter, 1990). However, in the case of millet, cultivated in three crop seasons, machinery traffic was lower because only planting and weeding operations were performed, with no mechanized applications of pesticides in the crop. This probably explains the non-effect of agricultural systems on soil physical attributes. There was interaction between soil depth and year for density and macroporosity. Density was higher in the initial year at $0-0.10 \mathrm{~m}$ depth, and macroporosity was lower in the initial year at the same depth.

Studies with longer duration indicate improvements in soil physical quality with crop rotation and introduction of cover crops. After seven years of crop rotation, Albuquerque et al. (1995) observed a
$0.07 \mathrm{Mg} \mathrm{m}^{-3}$ reduction in the 0.01 to $0.086 \mathrm{~m}$ layer of a Red-Dark Latosol. In Red Latosol cultivated for five years with cover crops, Argenton et al. (2005) reported that reduced preparation of gray mucuna improved soil physical quality, observed by the increase in macroporosity, total porosity, and hydraulic conductivity. Thus, in the present experiment, the time to evaluate changes in soil physical attributes provided by cover plants was small. Possibly, in longer periods of time, we could verify significant alterations in these attributes.

The accumulated grain, straw, and grain + straw yield was higher in the treatments with offseason cultivation compared to the treatments without this cultivation (Table 6). Limestone incorporation also provided significant increases in grain yield. 
Table 6 - Accumulated productivity of grains (APG), straw (APS) and grains plus straw (APG+S) due to the agricultural system, doses and incorporation (INC) of limestone.

\begin{tabular}{lccc}
\hline Tratamento & APG & $\begin{array}{c}\text { APS } \\
\left(\mathrm{kg} \mathrm{ha}^{-1}\right)\end{array}$ & APG+S \\
\hline With off-season crop & $23,155 \mathrm{a}$ & $29,354 \mathrm{a}$ & $52,509 \mathrm{a}$ \\
Without off-season crop & $18,506 \mathrm{~b}$ & $0 \mathrm{~b}$ & $18,506 \mathrm{~b}$ \\
\hline With INC & $21,145 \mathrm{a}$ & $14,735 \mathrm{a}$ & $35,880 \mathrm{a}$ \\
Without INC & $20,515 \mathrm{~b}$ & $14,619 \mathrm{a}$ & $35,134 \mathrm{a}$ \\
\hline CAL $\left(\mathrm{t} \mathrm{ha}^{-1}\right)$ & 20,808 & 15,050 & 35,858 \\
CAL $\left(\mathrm{t} \mathrm{ha}^{-1}\right) 1$ & 20,677 & 14,599 & 35,276 \\
CAL $\left(\mathrm{t} \mathrm{ha}^{-1}\right) 2$ & 20,625 & 15,234 & 35,859 \\
CAL $\left(\mathrm{t} \mathrm{ha}^{-1}\right) 3$ & 21,132 & 14,541 & 35,673 \\
CAL $\left(\mathrm{t} \mathrm{ha}^{-1}\right) 4$ & 20,909 & 13,961 & 24,870 \\
\hline Factors & & $\mathrm{F}$ test & \\
AS & $<0.0001$ & $<0.0001$ & $<0.0001$ \\
INC & 0.00128 & & \\
\hline
\end{tabular}

Factors: AS - agricultural systems (With off-season crop and Without off-season crop), SD soil depth; INC - incorporation or not of limestone; Means followed by the same lower-case letter in the column do not differ by $F$ test $(p>0.05)$.

There was no interaction between the factors (Table 6). Such behavior in relation to the agricultural systems was to be expected since in the system with off-season cultivation, soon after the first harvest, maize was cultivated intercropped with brachiaria, unlike the system without off-season cultivation. Thus, maize yield contributed to a higher accumulated grain yield of the system with compared to the system without off-season cultivation.

The diversification of crops for intensification of land use is now a necessity, both economically and environmentally (Kappes, 2015). In soils of constructed fertility, the current philosophy of fertilization of agricultural systems advocates operations to provide the soil with nutrients aiming to satisfy the absorption by the plants during a given period (Resende et al., 2016). Thus, it is important to determine the accumulated grain yields of the systems, involving different crops, to know the exports of nutrients by the grains and to plan replenishments, always considering a constant monitoring of the information made available in soil chemical analyses.

\section{Conclusion}

The agricultural system with off-season cultivation increased soil organic matter content and calcium and magnesium levels in the topsoil. There was no liming effect with up to four tons of limestone per hectare on soil chemical attributes measured four years after application. At the end of four years, soil density was lower and macroporosity was higher in the topsoil compared to the deepest layer. In the four-year period, agricultural systems with off-season cultivation of maize/brachiaria and millet provided greater grain and straw yields than agricultural systems without offseason cultivation.

\section{References}

Albuquerque JA, Reinert DJ, Fiorin, JE, Ruedel J, Petrere C, Fontinelll F (1995) Rotação de culturas e sistemas de manejo do solo: Efeito sobre a forma da estrutura do solo ao final de sete anos. Revista Brasileira de Ciência do Solo 19(1):115-119.

Altmann N (2001) Rotação de culturas: base da cobertura permanente do solo e da sustentabilidade em SPD. In: Encontro Regional de Plantio Direto no Cerrado, 5., 2001, Dourados. Anais... Dourados: Embrapa Agropecuária Oeste p. 29-30.

Alvares CL, Stape JL, Sentelhas PC, Goncalves JLM, Sparovek G (2014) Köppen's climate classification map of Brazil. Meteorologische Zeitschrift 22(6):711728.

Argenton J, Albuquerque JA, Bayer C, Wildner LP (2005) Comportamento de atributos relacionados com a forma da estrutura de Latossolo Vermelho sob sistemas de preparo e plantas de cobertura. Revista Brasileira de Ciência do Solo 29(3):425-435.

Braz AJBP, Silveira PM, Kliemann HJ, Zimmermann FJP (2004) Acumulação de nutrientes em folhas de milheto e dos capins braquiária e mombaça. Pesquisa Agropecuária Tropical 34(2):83-87.

Caires PE, Chueiri AW, Madruga EF (1998) Alterações de características químicas do solo e resposta da soja ao calcário e gesso aplicados na superfície em sistemas de cultivos sem preparo do solo. Revista Brasileira de Ciência do Solo 22(1):27-34.

Caires EF, Garbuio FJ, Alleoni LRF, Cambri MA (2006) Calagem superficial e cobertura de aveia preta antecedendo os cultivos de milho e soja em sistema plantio direto. Revista Brasileira de Ciência do Solo 30(1):87-98. 
Carmeis Filho ACA, Crusciol CAC, Castilhos AM (2017) Liming demand and plant growth improvements for an Oxisol under long-term no-till cropping. Journal of Agricultural Science 155(7):1093-1112.

Carter MR (1990) Relative measures of soil bulk density to characterize compaction in tillage studies of fine Sandy loam. Canadian Journal of Soil Science 70(3):425-433.

Carvalho MCS \& Nascente AS (2014) Calcário, gesso e efeito residual de fertilizantes na produção de biomassa e ciclagem de nutrientes de milheto. Pesquisa Agropecuária Tropical 44(2): 370-380.

Ceccon G (2007) Estado da arte na produção de palha com milho safrinha em consórcio com Brachiaria. Revista Plantio Direto 102, p.3-7.

Denardin JE \& Kochhann RA (1993) Requisitos para a implantação e a manutenção do sistema plantio direto. In: Centro Nacional de Pesquisa de Trigo/Embrapa Trigo; Fecotrigo; Fundação ABC. (Org.). PLANTIO DIRETO NO BRASIL. Passo Fundo: Aldeia Norte, p. $19-27$

Donagema GK, Campos DVB, Calderano SB, Teixeira WG (2011) Manual de métodos de análise de solo, 2. ed. Rio de Janeiro: Embrapa Solos. 212p.

Fageria NK, Nascente AS (2014) Management of soil acidity of South American soils for sustainable crop production. Advances in Agronomy 128:221-275.

Gatiboni LC, Saggin A, Brunetto G, Horn D, Flores JPC, Rheinheimer DS, Kaminski, J (2003) Alterações nos atributos químicos de solo arenoso pela calagem superficial no sistema plantio direto consolidado. Ciência Rural 33(2):283-290.

Kappes C (2015) Inserção do milho safrinha em sistemas de produção no mato Grosso In: Fundação Mato Grosso (Ed.). Boletim de Pesquisa 2015/2016. Santa Cruz do Sul, RS: Editora Gazeta p. 136-173.

Nascente AS, Silveira PM, Lobo Junior M, Guimaraes G, Cunha PCR (2014) Atributos químicos de latossolo sob plantio direto afetados pelo manejo do solo e rotação de culturas. Revista Caatinga. 27(1):153-163.
Nascente AS, Dambiro J, Constantino C (2017) Effects of grain-producing cover crops on rice grain yield in Cabo Delgado. Revista Ceres 64(6):607-615.

Pacheco LP, Leandro ML, Machado PLOA, Assis, RL, Cobucci T, Madari BE, Petter FA (2011) Produção de fitomassa e acúmulo e liberação de nutrientes por plantas de cobertura na safrinha. Pesquisa Agropecuaria Brasileira 46(1):17-25.

Pagani A, Mallarino AP (2012) Soil pH and crop grain yield as affected by the source and rate of lime. Soil Society of American Jounal 76(5):1877-1886.

Resende AV, Fontoura SMV, Borgh E, Santos FC, Kappes C, Moreira SG, Oliveira Junior A, Borin ALDC (2016) Solos de fertilidade construída: características, funcionamento e manejo. Informações Agronômicas 156:1-19.

SAS (1999) Statistical Analysis System User' Guide Statistics. SAS Institute Inc. Cary NC 27513 USA

Soratto RP, Crusciol CAC (2008) Atributos químicos do solo decorrentes da aplicação em superfície de calcário e gesso em sistema plantio direto recémimplantado. Revista Brasileira de Ciência do Solo 32(2):675-688.

Sousa DMG, Lobato E (2004) Cerrado: correção do solo e adubação. 2.ed. Brasília, DF: Embrapa Informação Tecnológica; Planaltina, DF: Embrapa Cerrados, $416 \mathrm{p}$. .

Tormena CA, Roloff G, Sá JCM (1998) Propriedades físicas do solo sob plantio direto influenciadas por calagem, preparo inicial e tráfego. Revista Brasileira de Ciência do Solo 22(2):301-309.

Walkley A, Black IA (1934) An examination of the degtyareff method for determining soil organic matter and a proposed modification of the cromic acid titration method. Soil Science 37:29-38. 